\title{
A Robust Frequency Control Approach in PV-Diesel Hybrid Power System
}

\author{
Heri Suryoatmojo ${ }^{1}$, Adi Kurniawan ${ }^{1}$, Feby Agung Pamuji ${ }^{1}$, Nursalim² ${ }^{2}$ IGP Suta Wijaya ${ }^{3}$, \\ and Herbert Innah ${ }^{4}$
}

\begin{abstract}
Hybrid power generation system such as photovoltaic (PV)-diesel is one of the solution to reduce operational cost of the conventional diesel generation system. However, fluctuation of $P V$ power due to uncertainty in weather condition may generate an unstable frequency of system. Further, it may reduce the reliability of the power utility, especially when the penetration of $P V$ power is large. Therefore, a frequency control approach that involving $P V$ with battery supervised by neural network algorithm is proposed to generate a stable system frequency. This method can reduce the frequency deviation without smoothing PV output power. The PV panels can generate maximum power according to the weather condition and frequency deviation. The PV output power and battery output power is controlled by neural network algorithm control. The neural network algorithm control is considering frequency deviation, average insolation and change of insolation as input. The proposed method is compared with similar system but without the existence of battery as energy storage system. The simulation results show that the proposed method can generate small frequency deviation compared with system without battery.
\end{abstract}

Keywords - hybrid power generation, pv-diesel, frequency deviation, neural network algorithm, energy storage system.

\section{INTRODUCTION}

$\mathrm{I}$ ndonesia is one of the largest archipelagos in the world which span more than $5,000 \mathrm{~km}$ from Sabang on the west to Merauke on the east. The total islands in Indonesia is more than 17,000 . Unfortunately, this geographical condition make the distribution of electrical energy in Indonesia become difficult. According to [1], until 2012, the electrification rate in Indonesia is only $75.8 \%$. It means that $22 \%$ from 25 millions of Indonesian population can't use electrical facilities yet. Mostly is in eastern part of Indonesia.

Most areas of eastern Indonesia are remote area. Some part of them is already has electric facilities. However, most of them are diesel generator that has high operational cost. This is causing a high electricity price in that area. Another problem is, diesel generator has notable issue with environment. Therefore, the use of renewable energy generation that has low operational cost and clean for the environment should be enhanced.

The most recommended renewable energy generation is photovoltaic (PV) because of it has no operation cost, low maintenance cost, no rotating part, quiet operation and produce no emission [2]. Compared with wind turbine, for example, PV is quieter and has lower maintenance cost though has larger investment cost per Watt.

However, it is not wise to shut down the use of existing diesel generator. So, the most promising application to be used is the hybrid PV-diesel generation. The diesel generator can also become the main supply when the renewable energy input is low. By combining renewable energy source such as PV, conventional energy source such as diesel generator and energy

${ }^{1}$ Heri Suryoatmojo, Adi Kurniawan, Feby Agung Pamuji are with Departement of Electrical Engineering, Faculty of Industrial Technology, Institut Teknologi Sepuluh Nopember, Surabaya, 60111, Indonesia. E-mail: suryomgt@ee.its.ac.id.

${ }^{2}$ Nursalim is with Departement of Electrical Engineering, Universitas Nusa Cendana, Kupang, Indonesia.

${ }^{3}$ IGP Suta Wijaya is with Departement of Electrical Engineering, Universitas Mataram, Mataram, Indonesia.

${ }^{4}$ Herbert Innah is with Departement of Electrical Engineering, Universitas Cendrawasih, Jayapura, Indonesia. storage system such as battery, the electrical cost can be reduced while the generation capacity is increase. Also, the more environmentally friendly system is established.

Unfortunately, this hybrid PV-diesel system has a major problem. The output power of PV system is depend on weather condition. If the weather conditions change frequently, the PV output power will have great fluctuations. Consequently, the system will experience a big frequency deviation, especially for the large PV system [3].

In reference [4], optimal controllers for diesel generator in hybrid PV-diesel generation are proposed. However, dynamic behaviour of PV array and inverter is not considered yet. In reference [5], the authors propose a method to generate maximum PV power in hybrid PVdiesel system by using coordinated management. It can fully exploit PV array power, but it is not solving the problem of frequency deviation.

In reference [6,7], a technique to smooth fluctuation of PV output power is developed. This technique can generate small frequency deviation. However, the use of this technique make the PV efficiency becomes lower because the maximum power of PV array can't be generated. Also, this method is actually not providing any frequency control. In reference [8], a new technique to smooth PV power that considering frequency control is proposed. However, the maximum PV power still can't be generated.

Reference [9] proposes new frequency control method for hybrid PV-diesel system. This new method can generate small frequency deviation without the need to smooth PV output power. Thus, the maximum PV power can be generated. The method is used fuzzy logic control that considering frequency deviation. However, it is need deep knowledge of the system to build optimal membership function and fuzzy rules. The simulation process is also a bit heavy for average computer.

Regarding those references, a new frequency control is proposed in this paper. The method is to reduce frequency deviation without smoothing PV power. The controller is based on Artificial Neural Network (ANN) algorithm that considering frequency deviation, average insolation and change of insolation as input. This ANN based controller generate reference power for PV array 
and battery. Different with fuzzy logic controller, there is no need to have deep knowledge of the system to build ANN based controller. The simulation process is also faster than system with fuzzy logic controller.

To validate the proposed method, the results are compared with similar system but without the existence of battery as energy storage system.

This content of this paper is as follows. Section II describes about the method used in this research. Section III shows the results and analysis. Section IV is the conclusion that made from this research.

\section{METHODOLOGY}

The whole power system model that used in this research is shown in Figure 1. The proposed system consist of PV panels, a boost converter, an energy storage system which is battery, a bidirectional buckboost converter, a diesel generator and three phase load. This system is represents the real power system in eastern part of Indonesia where the diesel generator is connected to the load with the addition of PV generator and battery. The combination of diesel generator, PV and battery can increase the total electric capacity in the system.

Aside from PV panels, battery, converter and diesel generator, there are two controller blocks that used in this system. The first controller is Maximum Power Point Tracking (MPPT) which is used to generate maximum power of PV system. The use of MPPT make the PV can generate maximum power in every condition of temperature and sun irradiance. The presence of MPPT can enhance the efficiency of PV power.

The second controller is the frequency deviation controller proposed in this research. The controller is based on ANN and generate command signal for three phase inverter and bidirectional buck-boost converter. The inputs for this controller system are sun irradiance and the change of frequency deviation.

The PV system characteristic and model, boost converter model, battery model, buck-boost bidirectional converter model, three phase inverter model, diesel generator model and controller design will be explained in sub-section of this section.

\section{A. PV System Characteristic and Model}

The equivalent circuit of PV panel can be modeled as a current source that is connected in parallel with a diode, a shunt resistance and a series resistance. Those resistances affect the output current of PV panels. The equivalent circuit is shown in Figure 2.

The output current of a PV module can be calculated as follow:

$$
I=I_{L}-I_{D}\left[e^{q\left(\frac{V+I R_{S}}{n k T}\right)}-1\right]-\left(\frac{V+I \cdot R_{s}}{R_{s h}}\right)
$$

The PV model used in this research is KC200GT Model that presented in [10]. The parameters of the PV modules are shown in Table 1 . The voltage-current and voltage-power characteristic curves of this module are shown in Figure 3.

A KC200GT module has $200 \mathrm{~W}$ maximum power on ideal condition. The rated PV output power that used in this research is $40 \mathrm{~kW}$ obtained from $200 \mathrm{PV}$ modules. The arrangement is 10 series and 20 parallel modules.

\section{B. Boost Converter Model}

In this research, boost converter is used to make PV power to be same with maximum power generated by MPPT block. Boost converter that used in this research is KY boost converter that proposed in [11].

KY boost converter has two superiorities than conventional boost converter. KY boost converter has faster transient response and smaller output voltage ripple than conventional boost converter. The fast response of this converter is very suitable to handle the rapid change of $\mathrm{PV}$ power due to the change of weather condition. The small voltage ripple generated by this converter can results longer lifetime for the equipment. The only weakness of KY boost converter is smaller output voltage range than conventional boost converter.

KY boost converter consists of two MOSFET, $\mathrm{S}_{1}$ and $\mathrm{S}_{2}$, which work as switch,two diodes $\mathrm{D}_{1}$ and $\mathrm{D}_{2}$, a diode $\mathrm{D}_{\mathrm{b}}$, an energy transfer capacitor $\mathrm{C}_{\mathrm{b}}$, an output inductor $\mathrm{L}$, and an output capacitor $\mathrm{C}$. The configuration of $\mathrm{KY}$ boost converter is shown in Figure 4. The relationship of input voltage, duty cycle and output voltage of KY boost converter is as follow:

$$
\begin{aligned}
& V o_{K Y}=V p v(1+D) \\
& D=\frac{t S_{1} \text { on }}{T} \\
& T=\frac{1}{f_{\text {switching }}} \\
& \text { C. MPPT Model }
\end{aligned}
$$

The voltage-power characteristic curve in Figure 3 shows that the maximum power of PV module in certain weather condition can be obtained when PV voltage is on certain point called $\mathrm{V}_{\mathrm{mpp}}$. If the $\mathrm{PV}$ output voltage is smaller or bigger than $\mathrm{V}_{\mathrm{mpp}}$, $\mathrm{PV}$ module is not generating maximum power. MPPT works by tracking $\mathrm{V}_{\mathrm{mpp}}$ on every condition of temperature and sun irradiance. Then, KY boost converter will make PV generate output voltage that same with $\mathrm{V}_{\mathrm{mpp}}$, and as the result, $\mathrm{PV}$ will generate maximum available power in that weather condition.

MPPT algorithm that used in this study is based on ANN. The input of the MPPT block is temperature and sun irradiance that assumed to be same for all PV modules.

\section{Battery Model}

The presence of energy storage system such as battery is very important in a hybrid power system that involving renewable energy sources such as PV. Battery can compensate the mismatch in power between the generation power and the load. The mismatch in power can appear because of the rapid change in sun irradiance. When the PV power is smaller than inverter reference power, battery will supply power to the load. When the $\mathrm{PV}$ power is bigger than the inverter reference power, the excess power will be stored in battery.

PV can't operate at the night because there is no sun irradiance. The existence of the battery can help to increase power capacity at night. Although without PV 
power, the combination of diesel and battery is more economical than system that only consists of diesel generator.

The battery model developed in [12] is used in this research. The important parameters of battery are voltage, capacity and state of charge (SOC). Battery can be modeled as a controllable voltage source that connected in series with a resistance. The SOC and output voltage of battery is calculated using gassing current model, capacity model, voltage model and SOC model. The structure of this model is shown in Figure 5 where VBB is the voltage of battery, CB is actual battery capacity, IMR is the reaction current, TBB is external battery temperature, IGA is gassing battery current and IBB is the external battery current. The parameters of the battery that used in this research are written in Table 2.

\section{E. Bidirectional Buck-Boost Converter}

Buck-Boost bidirectional converter is used to maintain voltage at dc bus and excecute charging and discharging process of the battery. When the PV power generation is larger than inverter reference power, the bidirectional converter will operate as buck converter and the electric power will flow from DC bus to battery. When the condition is vice versa, the bidirectional converter will operate as boost converter and the electric power will flow from the battery to the dc bus and then to the load.

The type of bidirectional buck-boost converter that used in this research is bidirectional inverse $\mathrm{KY}$ converter that proposed in [13]. When operating in boost mode, this converter has non-pulsating output current and fast transient response. In buck mode, this converter has non-pulsating input current. Those advantages make bidirectional inverse KY converter better than conventional buck-boost converter.

The topology of this converter is shown in Figure 6. This converter consists of three MOSFET, $S_{1}, S_{2}$ and $S_{3}$, which work as switch, three diodes $\mathrm{D}_{1}, \mathrm{D}_{2}$ and $\mathrm{D}_{3}$, an energy transfer capacitor $\mathrm{C}_{\mathrm{b}}$, an series inductor $\mathrm{L}$ and two parallel capacitor $\mathrm{C}_{1}$ and $\mathrm{C}_{2}$ on each side.

When operating as buck mode, the relationship of the battery voltage, duty cycle and dc bus voltage is as follow:

$\frac{\mathrm{V}_{\text {batt }}}{\mathrm{V}_{\mathrm{dc}-\text { bus }}}=\frac{1}{2-\mathrm{D}}$

When operating as boost mode, the relationship change as follow:

$\frac{\mathrm{V}_{\mathrm{dc}-\text { bus }}}{\mathrm{V}_{\text {battery }}}=1+\mathrm{D}$

\section{F. Battery Controller Model}

Battery controller is drive the switch on bidirectional buck-boost converter. This controller has function to maintain the dc bus voltage to be constant at $350 \mathrm{~V}$. The $\mathrm{dc}$ bus voltage is set to $311 \mathrm{~V}$ because it has to be higher than maximum line-to-netral of AC voltage which is 311 $\mathrm{V}$.

\section{G. Three Phase Inverter Model}

Three phase inverter is also bidirectional. The inverter converts DC voltage into three phase AC voltage when battery is in discharging mode. When the battery is in charging mode, this inverter converts three phase AC voltage model into DC voltage. A regular six pulse three phase inverter is used in this research. The inverter is controlled by ANN based controller that developed in this study.

\section{H. Inverter Controller Model}

The main purpose of this research is to develop a robust frequency control for hybrid PV-diesel power system. There is no new neural network development here, rather an active power control based on load and sun irradiance variation is presented by using neural network. The algorithm of neural network is using Levenberg-Marquardt back-propagation algorithm.

The inverter controller use sun irradiance and load frequency deviation as its input. The output of this controller is reference power for three phase inverter. The reference power that generated by this controller is the power that will provide minimum frequency deviation for the system.

The structure of the controller is shown in Figure 7. It is consist of two ANN blocks. The first block use average sun irradiance and frequency deviation as its inputs. The second block use average sun irradiance and the change of frequency deviation as its inputs. Each block will generate a control signal. These two control signal will be summed and used to calculate reference power following this equation:

$P_{\text {inv }}^{*}=P_{\text {rated }}\left\{\gamma(k)+\frac{\gamma(k+1)-\gamma(k)}{T_{s}} t\right\}$

Where Prated is PV rated power, Ts is the sampling time and $\mathrm{t}$ is time when the data is taken.

\section{Diesel Model}

The diesel model in this research is used standard model developed in [14]. Figure 8 shows the block diagram of the diesel. The input of this model is load demand PL. The parameters of speed governor are represented by the integral control gain $\mathrm{Ki}$ and the droop $\mathrm{R}$. Time constant Tsm in governor model is represent valve actuator. The output of this diesel model is electrical frequency deviation. Parameters of the diesel that used in this system is shown in Table 3.

\section{RESULT AND DISCUSSION}

The proposed system is simulated in computer to examine its effectiveness. To observe the effectiveness of the proposed system, the results from the proposed system is compared with system without battery. The proposed inverter controller can't be used in system without battery because the working principle of the proposed controller is regulating the battery power. The inverter controller in system without battery only regulates the output $\mathrm{AC}$ voltage of the inverter. The total simulation time is 800 seconds while the sampling time is 1 second. The temperature is assumed to be constant at $25^{\circ} \mathrm{C}$. The sun irradiance and load data are not taken from real data yet. The sun irradiance is use random number between 600 and $1000 \mathrm{~W} / \mathrm{m}^{2}$ with mean value of $800 \mathrm{~W} / \mathrm{m}^{2}$. The three phase load given in this research is random number between 60 and $100 \mathrm{~kW}$ with mean value of $80 \mathrm{~kW}$. The graphic of sun irradiance and three phase load is shown in Figure 9.

Simulation results of system without battery are shown in Figure 10. Figure 10 (a) shows PV output power while Figure 10 (b) shows diesel output power. The PV output 
power is between 25 and $38 \mathrm{~kW}$ depends on the sun irradiance while the diesel output power is between 15 and $60 \mathrm{~kW}$.

Simulation results of system with battery are shown in Figure 11. Figure 11 (a) shows PV output power while Figure 11 (b) shows diesel output power and Figure 11 (c) shows battery output power. The PV output power on system with battery is not different with PV output power on system without battery because it is resulted from MPPT controller. The maximum diesel output power is a bit smaller than in system without battery because the system gets the addition of power generation from battery. The battery power shows some positive and negative values. The positive value indicates that the battery is supplying power to the load. The negative values mean that the battery is in charging mode.

The effectiveness of the proposed system can be seen from comparison of frequency deviation that shown in Figure 12. The frequency deviation is measured in per unit (p.u.) value. The blue line shows the frequency deviation of system without battery. The smoother one, the red line, shows the frequency deviation of system with battery. The frequency deviation of system with battery is only oscillate between $9.3 \times 10^{-3}$ and $9.7 \times 10^{-3}$ p.u. or 0.46 and $0.48 \mathrm{~Hz}$. The frequency deviation of system without battery is bigger, which is $8.6 \times 10^{-3}$ $10.2 \times 10^{-3}$ p.u. or 0.43 and $0.51 \mathrm{~Hz}$. This results show that the proposed system can generate low frequency deviation for the hybrid pv-diesel system. The difference between the results from those two systems is not big, but it will be bigger if the load demand and sun irradiance are more varied. In the future research, the load demand, sun irradiance and temperature value will use the real value that measured in certain location.

\section{CONCLUSION}

The objective of this study is to design a hybrid PVdiesel system with low frequency deviation. Comparison of simulation results between the proposed system and similar system without the existence of battery show that the proposed system is able to generate smaller frequency deviation of hybrid PV-diesel system. The difference is not too great due to good value of sun irradiance and load demand. In the next research, the real sun irradiance and load demand data that more varied than in this paper will be applied to the system.

\section{REFERENCES}

[1]. Kementerian ESDM Republik Indonesia, "Statistik listrik 2012," 2012.

[2]. Syafarudin, E. Karatepe, T. Hiyama, "Polar coordinated fuzzy controller based real-time maximum-power point control of photovoltaic system," Science Direct - Renewable Energy, vol. 34, pp. 2597-2606, 2009.

[3]. M. Rashed, A. Elmitwally, S. Kaddah, "New control approach for a PV-diesel autonomous power system," Science Direct - Electric Power System Research, vol. 78, pp. 949-956, 2008.

[4]. E.S. Abdin, A.M. Osheiba, M.M. Khater, "Modeling and optimal controllers design for a stand-alone photovoltaic-diesel generator unit," IEEE Trans.Energy Conversion, vol. 14, no. 3, pp. 560$565,1999$.

[5]. D. Canever, G. J. W. Dudgeon, S. Massucco, J. R. McDonald, and F. Silve-stro, "Model validation and coordinated operation of a photovoltaic array and a diesel power plant for distributed generation," in Proc. Of IEEE Power Eng. Soc. Summer Meeting 2001, vol. 1, pp. 626-631, 2001.

[6]. N. Ina, S. Yanagawa, T. Kato, and Y. Suzuoki, "Smoothing of PV system output by tuning MPPT control," Elect. Eng. Japan., vol. 152, no. 2, pp. 10-17, 2005.

[7]. J.-S. Park, T. Katagi, S, Yamamoto, T. Hashimoto, "Operation control of photovoltaic/diesel hybrid generating system considering fluctuation of solar radiation," Solar Energy Mater. Solar Cells, vol. 67, no. 1-4, pp. 535-542, Mar. 2001.

[8]. M. Datta, T. Senjyu, A. Yona, T. Funabashi, C.H. Kim, “A coordinated control method for leveling PV output power fluctuations of PV-diesel hybrid systems connected to isolated power utility," IEEE Trans. Energy Conversion, vol. 24, no. 1, pp. 153-162, Mar. 2009.

[9]. M. Datta, T. Senjyu, A. Yona, T. Funabashi, C.H. Kim, "A frequency control approach by photovoltaic generator in a PVdiesel hybrid power system," IEEE Trans. Energy Conversion, vol. 26, no.2, pp. 559-571, June 2011

[10]. M. G. Villalva, J. R. Gazoli, E. Ruppert, "Modeling and circuitbased simulation of photovoltaic arrays," Brazilian Journal of Power Electronics, vol. 14, no. 1, pp. 35-45, 2009.

[11]. K.I. Hwu, Y.T. Yau, "A novel voltage-boosting converter : KY converter" in Proc Of Applied Power Electronics Conference (APEC), pp. 368-372, 2007.

[12]. A. Al-Alawi, S. M. Al-Alawi, S. M. Islam, "Predictive control of an integrated PV-diesel water and power supply system using an artificial neural network," Science Direct - Renewable Energy, vol. 32, pp. 1426-1439, 2007.

[13]. K.I. Hwu, Y.H. Chen, "Bidirectional control of inverse KY converter," in Proc Of IEEE International Symposium on Industrial Electronics (ISIE2009) Seoul Olympic Parktel, Seoul, Korea, July 5-8, 2009.

[14].S. A. Papathanassiou, M. P. Papadopoulos, "Dynamic characteristics of autonomous wind-diesel systems," Science Direct - Renewable Energy, vol. 23, pp. 293-311, 2001.

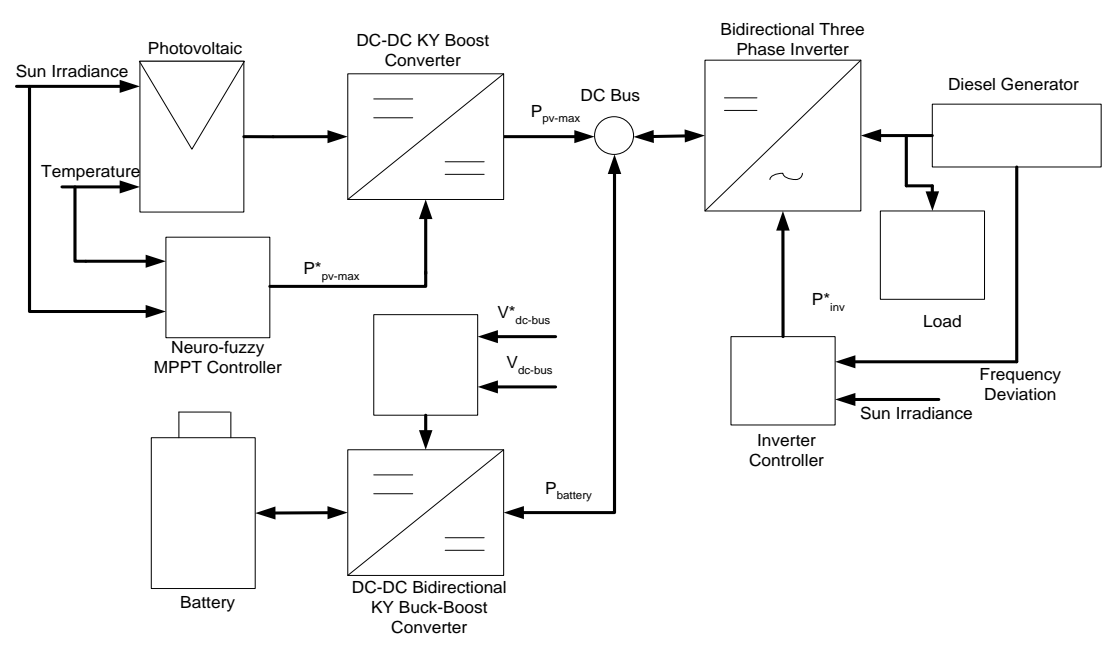

Figure 1. Configuration of proposed system 


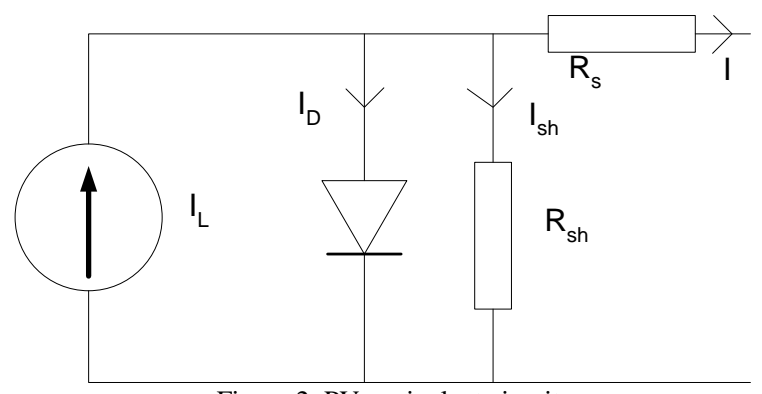

Figure 2. PV equivalent circuit
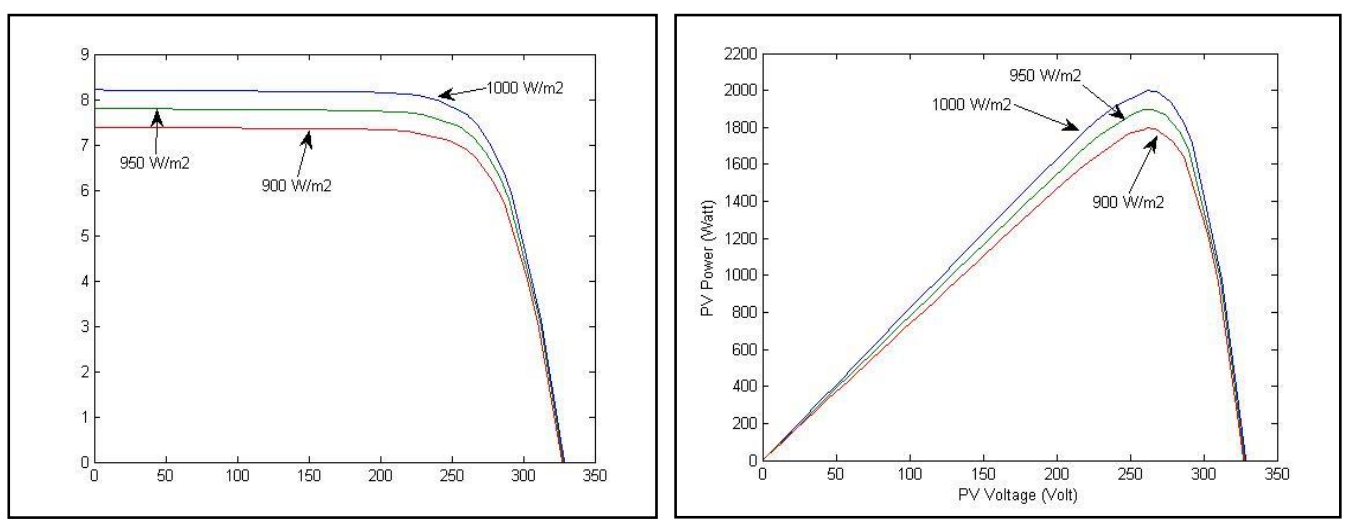

Figure 3. PV Characteristic Curve at $25^{\circ} \mathrm{C}$ temperature with different sun irradiance (a) V-I Curve (b) V-P Curve

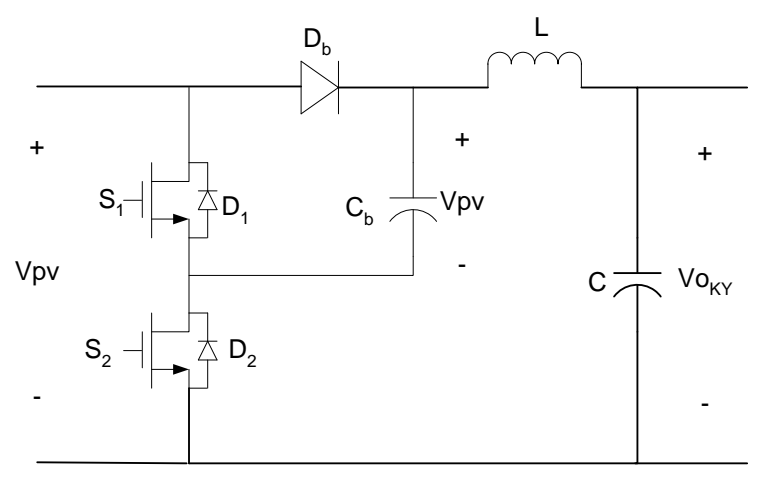

Figure 4. Topology of KY boost converter

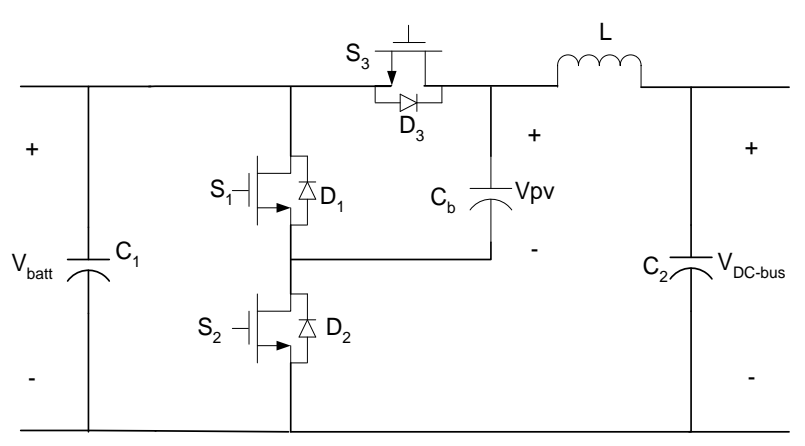

Figure 6. KY bidirectional buck-boost converter topology

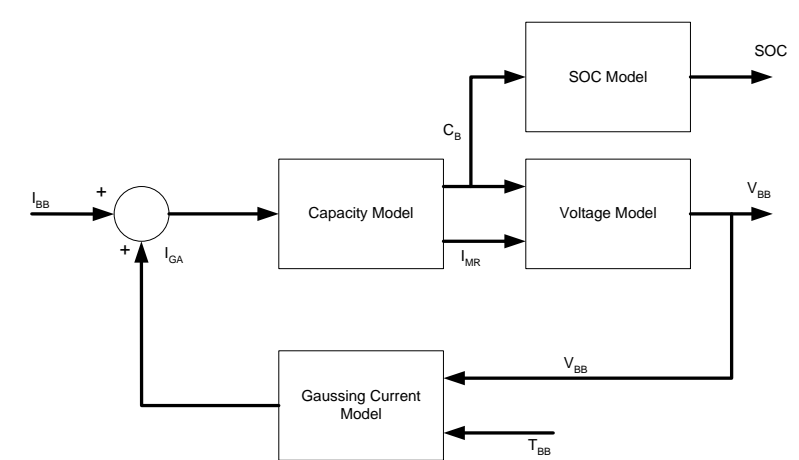

Figure 5. Battery model

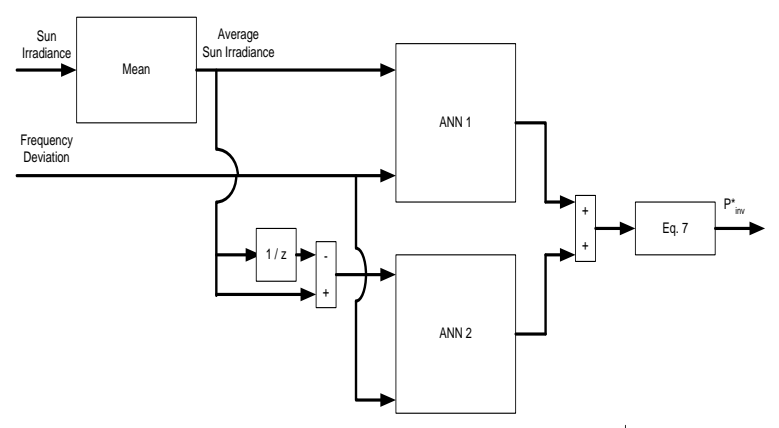

Figure 7. Inverter controller model

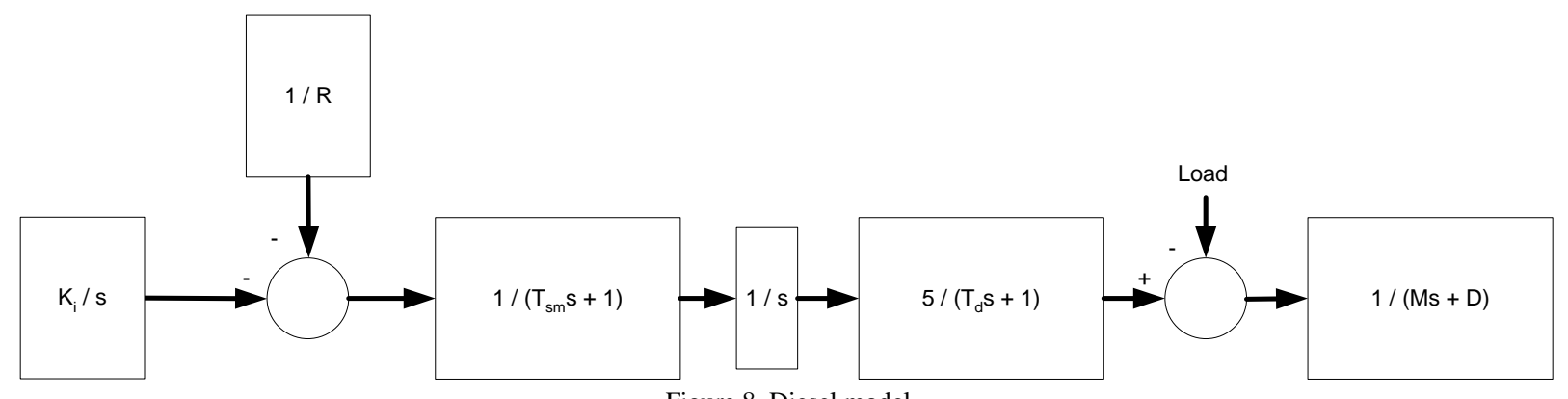

Figure 8. Diesel model 


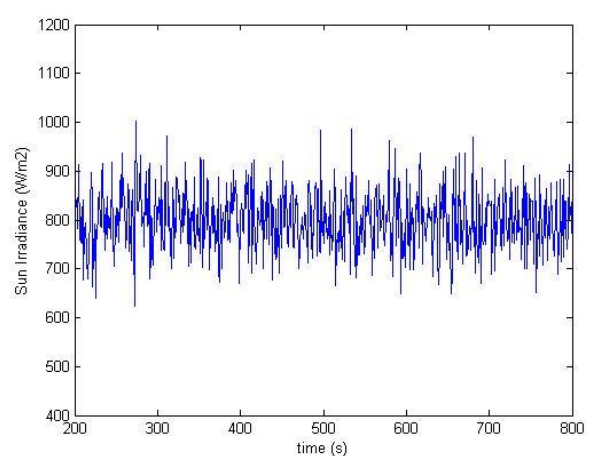

(a)

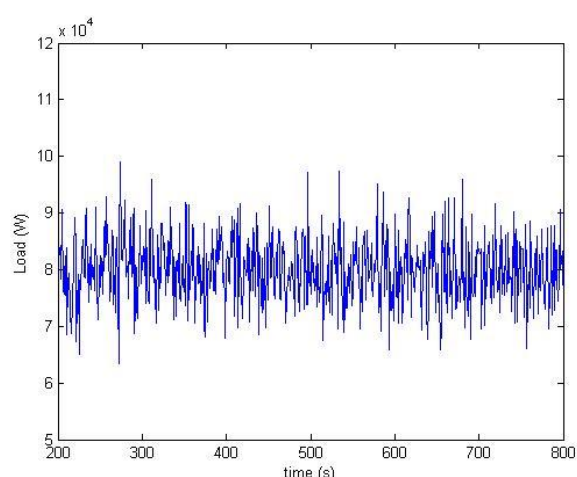

(b)

Figure 9. Sun irradiance and load demand (a) Sun irradiance (b) Load demand

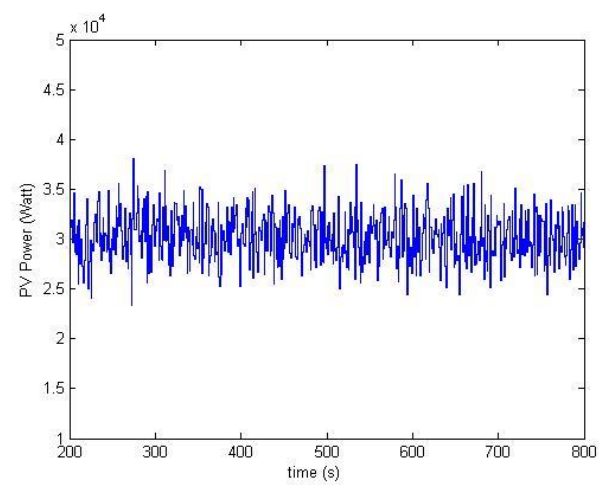

(a)

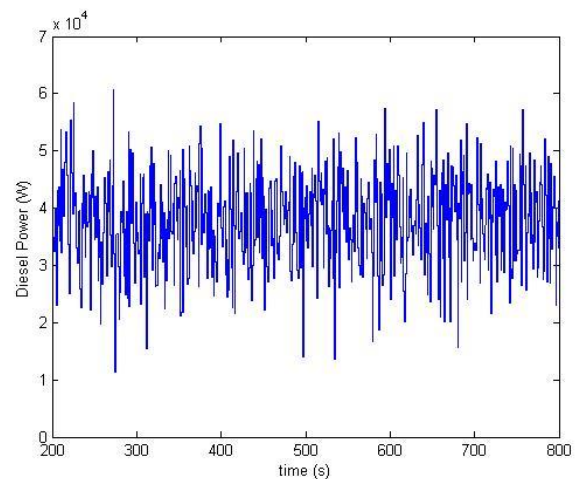

(b)

Figure 10. Results of system without battery (a) PV output power (b) Diesel output power

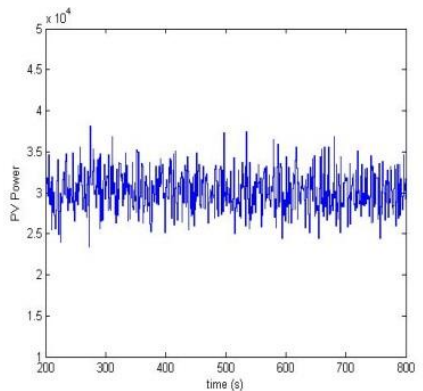

(a)

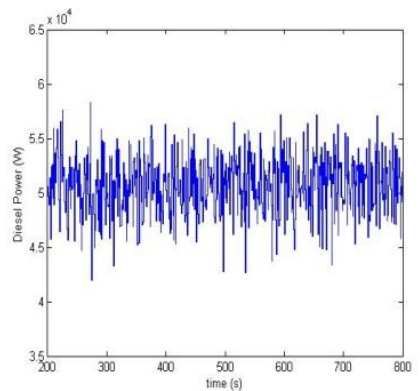

(b)

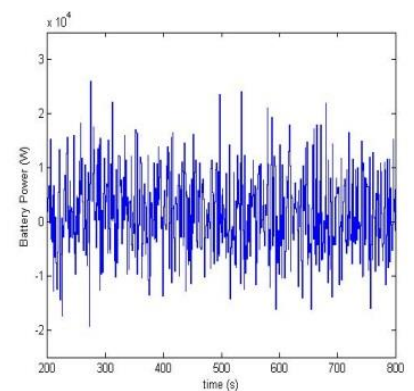

(c)

Figure 11. Results of system with battery (a) PV output power (b) Diesel output power (c) Battery power

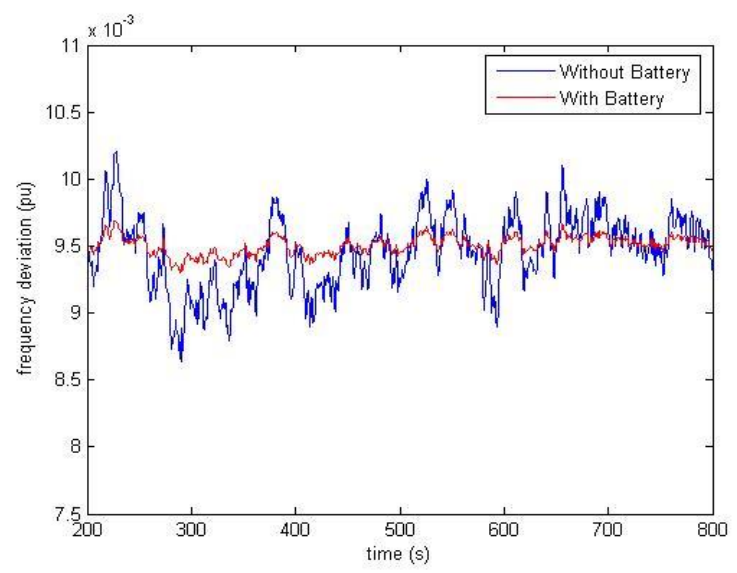

Figure 12. Comparison of frequency deviation 
TABLE 1.

PARAMETER OF PV MODULES

\begin{tabular}{|c|c|c|}
\hline No. & Parameter & Value \\
\hline 1 & Current at Maximum Power & $7.61 \mathrm{~A}$ \\
\hline 2 & Voltage at Maximum Power & $26.3 \mathrm{~V}$ \\
\hline 3 & Maximum Power & $200 \mathrm{~W}$ \\
\hline 4 & Short Circuit Current & $8.21 \mathrm{~A}$ \\
\hline 5 & Open Circuit Voltage & $32.9 \mathrm{~V}$ \\
\hline 6 & Parallel Resistance & $415.405 \Omega$ \\
\hline 7 & Series Resistance & $0.221 \Omega$ \\
\hline 8 & Number of Series Panels & 10 \\
\hline 9 & Number of Parallel Panels & 20 \\
\hline 10 & Rated Capacity of PV Array & $40 \mathrm{~kW}$ \\
\hline
\end{tabular}

TABLE 2.

PARAMETER OF BATTERY

\begin{tabular}{|c|c|c|}
\hline No. & Parameter & Value \\
\hline 1 & Nominal Voltage & $240 \mathrm{~V}$ \\
\hline 2 & Fully Charged Voltage & $283 \mathrm{~V}$ \\
\hline 3 & Nominal Discharging Current & $25 \mathrm{~A}$ \\
\hline 4 & Total Rated Capacity & $30 \mathrm{kWh}$ \\
\hline \multicolumn{3}{|c|}{$\begin{array}{c}\text { TABLE } 3 . \\
\text { PARAMETER OF DIESEL } \\
\end{array}$} \\
\hline No. & Parameter & Value \\
\hline 1 & Governor Time Constant, $T_{s m}$ & $0.1 \mathrm{~s}$ \\
\hline 2 & Diesel Time Constant, $T_{d}$ & $5 \mathrm{~s}$ \\
\hline 3 & Total Rated Capacity & $60 \mathrm{~kW}$ \\
\hline
\end{tabular}

